\title{
Entrepreneurial orientation and new venture resource acquisition: why context matters
}

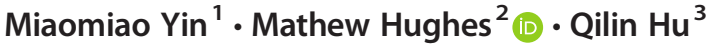

Published online: 1 May 2020

(C) The Author(s) 2020

\begin{abstract}
Resource acquisition is vital for new venture survival and growth. However, surprisingly little is known about how the entrepreneurial orientation (EO) of the new venture affects its resource acquisition. Drawing on the resource-based view of the firm, we articulate a theory and treatment of EO that address this oversight and remedy for the routine absence of context among studies of EO. Accounting for the simultaneous effect of environmental dynamism and an opportunistic orientation (OO), a tendency among Chinese new ventures to imitate technology and profit through market information asymmetry, as important contextual variables reflecting the Chinese business context, we provide insights on the contingency effects of contextual variables. Results from a quantitative study of 361 Chinese new ventures show that EO positively influences resource acquisition. However, this relationship is context sensitive. In a low dynamic environment, OO negatively moderates this relationship. However, in a highly dynamic environment, OO exhibits no effect on the relationship between EO and new venture resource acquisition. Our results contribute to a resource-based theory of EO and reveal its context sensitivity. Our study is a step in moving the scholarship of EO forward and away from the performance debate towards greater predictive accuracy of EO and its systems of effects.
\end{abstract}

Keywords Entrepreneurial orientation - Opportunistic orientation - Resource acquisition · Environmental dynamism $\cdot$ Resource-based view $\cdot$ China $\cdot$ New ventures $\cdot$ Context Theory of the firm

Mathew Hughes

m.hughes2@lboro.ac.uk

Miaomiao Yin

yinmiaomiao@jlu.edu.cn

Qilin $\mathrm{Hu}$

qilin.hu@dmu.ac.uk

Extended author information available on the last page of the article 
Entrepreneurial orientation (EO), an attribute of a new venture that manifests as a strategic posture based on the extent to which the firm exhibits a sustained pattern of risk-taking, innovative and proactive behavior (Covin \& Wales, 2019), has attracted considerable scholarly attention over the past two decades. EO is particularly popular among Asian (Hughes, Hodgkinson, Arshad, Hughes, \& Leone, 2018a; Hughes, Hodgkinson, Hughes, \& Arshad, 2018b) and Chinese studies (Cui, Fan, Guo, \& Fan, 2018; Zheng \& Zhao, 2017) because a disposition towards entrepreneurship among new ventures is vital to long-term competitiveness in economically-burgeoning and increasingly market-oriented countries such as China (e.g., Miller, 2011). New venture success promotes economic growth and social well-being in China (Cui et al., 2018). However, the Chinese context is complex and unstable (Zhou \& Li, 2010), and studies suggest that the best effects of EO in Chinese new ventures are very likely to rely on contingencies tied to the Chinese context (e.g., Cui et al., 2018). Yet, these contingencies rarely receive recognition (Yiu, Lam, Gaur, Lee, \& Wong, 2018) and are symptomatic of a general disregard for contextual variables among studies of EO (see Zahra, Wright, \& Abdelgawad, 2014). This oversight matters. For instance, EO is a resourceintensive strategic posture (Hughes, Eggers, Kraus, \& Hughes, 2015) and because of its emphasis on simultaneously risky, innovative, and forward-looking behavior, may result in costly failures unless a complementary orientation provides some stability and control (Covin \& Wales, 2019). The behaviors attributed to EO are also path dependent, creating ever-increasing internal resource demands to sustain its exploratory tendencies (Hughes, Hughes, \& Morgan, 2007), and its effects may be attenuated by country-specific contextual factors (Kraus, Rigtering, Hughes, \& Hosman, 2012; Saeed, Yousafzai, \& Engelen, 2014; Semrau, Ambos, \& Kraus, 2016). The tendency in EO studies to relegate contextual factors to the status of control variables means that vital contingency effects are missed (Zahra et al., 2014). Consequently, theory and treatment of the effects of EO on new ventures' resource acquisition, and the context sensitivity of this relationship, are essential to moving the scholarship of EO away from the debate about performance and towards a greater depth of understanding of its system of effects (Covin \& Wales, 2019).

The process of resource acquisition to construct an initial resource base is an exceptional challenge for new ventures (Brush, Greene, Hart, \& Haller, 2001b). Acquiring resources is a vital entrepreneurial task for new ventures because a failure to attract or acquire adequate resources from the institutional, competitive and social environments carries the risk of converting a new venture's liabilities of newness into fatal disadvantages (Cai, Hughes, \& Yin, 2014; Zhang, Soh, \& Wong, 2010). While a small group of extant studies examine how EO affects the acquisition of information and knowledge resources (e.g., Jiang, Liu, Fey, \& Jiang, 2018; Jiang, Wang, \& Jiang, 2019; Keh, Nguyen, \& Ng, 2007), many new ventures fail to attract the financial and competitive resources necessary to grow and prosper from external resource holders. Unveiling the relationship between EO and resource acquisition can add much to our understanding of how and when EO may solve this problem among new ventures (e.g., Jiang et al., 2018).

We use the resource-based theory of the firm (RBV) to predict the interaction of EO with contextual elements of the Chinese business context to predict its contribution to new ventures' resource acquisition. A review of previous studies reveals a possible reason why scholars have found different views about the role played by EO in new 
ventures: the potential sensitivity of EO to context (Covin \& Miller, 2014). For example, China is experiencing an economic transition led by 'Xi Jinping Thought' and exhibits a series of unique characteristics (Berger, Herstein, Silbiger, \& Barnes, 2018). Its institutions are not perfect or stable (Cui et al., 2018), property right laws are immature (Shou, Chen, Zhu, \& Yang, 2014; Zhou \& Poppo, 2010), and market information is not transparent (Cui et al., 2018). Under these conditions, variations in actual and perceived levels of environmental dynamism are high, and many new ventures succeed by acting opportunistically to imitate current technology (Dong, Ma, \& Zhou, 2017; Luo, Sun, \& Wang, 2011) (exhibiting an opportunistic orientation) rather than innovate entrepreneurially. Other than EO, new ventures can grow by acquiring essential productive resources at low cost and reforming them into imitative products at a high price when asymmetric competitive conditions are present. Because of difficulties in acquiring resources for sustained business activity, growth, or technology innovation (Cui et al., 2018), many new ventures opt to imitate currentlypopular technologies instead of, or together with, innovating. This behavior is consistent with the characteristics of risk aversion present in Chinese culture ( $\mathrm{Ma}, \mathrm{Yu}, \mathrm{Gao}$, Zhou, \& Yang, 2015). Imitating technology and making profits through market information asymmetry constitute the content of an opportunistic orientation (OO) (Anokhin, Troutt, Wincent, \& Brandyberry, 2010; Anokhin, Wincent, \& Autio, 2011). OO is an important contextual variable that reflects specific elements of the Chinese business context, but has hitherto escaped analysis beyond its origin in arbitrage. China is also a substantially large country, and its entrepreneurial environment varies in its effects on firms (Zheng \& Zhao, 2017). For example, changes in market demand and improvements in technology occur quickly and unpredictably in southern and central areas, indicating high environmental dynamism (Li \& Liu, 2014; Zhou \& Li, 2010). However, those changes in the northwestern area are slower (Zheng \& Zhao, 2017) and where environmental dynamism is lower (Li \& Liu, 2014; Zhou \& $\mathrm{Li}, 2010$ ). Variations in environmental dynamism may further mitigate the usefulness of EO for new venture resource acquisition because the business context may not reward the behaviors associated with EO and instead place a premium on opportunistic imitation and reward copycat behavior. An opportunistic orientation may work alongside EO to facilitate resource acquisition under certain degrees of environmental dynamism but work against it in others by creating competing positions that confuse resource holders in strategic factor markets about firm strategies. Given the vulnerability of new ventures to liabilities of newness, combining orientations in ways that cause strategic confusion in a given context risk the viability of the venture by undermining its efforts to establish legitimacy (e.g., Sine, Mitsuhashi, \& Kirsch, 2006). Given this theoretical dilemma, we answer the following research question: To what extent is a potential relationship between EO and new venture resource acquisition context sentence to environmental dynamism and the concurrent exhibition of an opportunistic orientation?

We analyze data from 361 Chinese new ventures to answer this question. We provide three contributions to theory and knowledge. First, in examining the relationship between EO and resource acquisition, we reveal how EO plays its role in new ventures. Extending the RBV, we overcome deficits in existing theory that do not explain the mechanisms by which EO may help or hinder new venture resource acquisition. For example, while studies of the EO-performance relationship 
normatively assume that firms with greater EO are better at resource acquisition (Huang \& Wang, 2013; Hughes \& Morgan, 2007; Lumpkin \& Dess, 1996), when and why this is so is mostly speculated and untested. We present a theoretical logic that sees EO as a resource-intensive orientation that initiates a search process to acquire resources to both refuel the new venture and to enable its entrepreneurially-oriented endeavors to come to life. We expect EO to drive resource acquisition efforts in the new venture and offer an empirical contribution and theoretical justification to this end, but on the proviso that its success will depend on contextual factors. Second, we enrich the study of EO and the $\mathrm{RBV}$ by integrating an opportunistic orientation (OO), a second strategic orientation especially prevalent in the Chinese context for entrepreneurship. Covin and Wales (2019) argue that EO can be especially disruptive and unproductive in ways that suggest a second complementary orientation that promotes stability and focus is necessary to optimize its contribution. Works complementary to the RBV highlight failure and competency traps when firms are excessively entrepreneurial or excessively stability focused (Levinthal \& March, 1993). We integrate OO (Anokhin et al., 2010, 2011) to capture how firms exploit market information asymmetry with technology imitation. We contribute to knowledge on EO by mapping a theoretical treatise and framework that includes the influences of the Chinese propensity for $\mathrm{OO}$ on new ventures' actions to observe differences in how EO may on occasions be productive and unproductive in resource acquisition terms. Third, although existing studies claim to treat the Chinese context, these studies often do so as background only (Jia, You, \& Du, 2012; Zheng \& Zhao, 2017). This tendency is common across studies of entrepreneurship where context is often relegated to the status of a control variable or ignored entirely (Zahra et al., 2014), especially in Asian management research (Yiu et al., 2018). Theoretical development on EO lacks substantive treatment of its context sensitivity. We remedy this failing by comparing the moderating effects of $\mathrm{OO}$ on the relationship between EO and resource acquisition in high and low dynamic environments to capture within-country perceived heterogeneity in the landscape of the competitive environment. We offer a complex model that not only provides us with insights on a moderating effect of $\mathrm{OO}$, but also accounts for contextual variables. Collectively, these contributions advance knowledge on EO, its system of effects, and the boundary conditions of its contribution to new venture resource acquisition, revealing how, when and why EO may enhance new venture resource acquisition.

\section{Theoretical background and hypotheses development}

\section{A resource-based view of entrepreneurial orientation and opportunistic orientation}

New ventures must become bundles of productive resources to create the competitive advantages that enable their survival and growth (Barney, 1991; Barney, Wright, \& Ketchen, 2001). Under the resource-based view (RBV), theoretically, amassing and acquiring new resources have been associated with superior firm performance (Cai et al., 2014; Cui et al., 2018), consistent with the internal logic of the resource-based view (Barney, 1991; Li \& Liu, 2014). Early treatments of the RBV in strategy management emphasized the possession of those resources bearing specific properties as being the most important for firms to possess. Resources that were judged valuable, 
rare, inimitable and non-substitutable (so-called VRIN resources) offered the basis for competitive advantage (Wernerfelt, 1984). However, their possession is not enough and, as a theory of the firm, later revisions placed a premium on the firm as an organizing mechanism to make effective use of resources for productive outcomes (Barney, 1991). Subsequent works focused explicitly on the firm as an organization mechanism, in which resources held became secondary to the capacity (or capability) for productive utilization of the resource base (Barney et al, 2001). While the possession of resources assists a firm in attaining competitive advantage in the short term, sustaining that advantage requires the new venture to (a) reconfigure and reconstitute its resources in keeping with its external environment and (b) to replenish its resource base so that the mechanism it uses to create wealth (its strategic orientation) is lubricated and fuelled (e.g., Barney et al., 2001; Sirmon, Hitt, Ireland, \& Gilbert, 2011).

As a theory of the firm, the RBV takes the position that new ventures form as a better solution to make effective use of an initial bundle of resources against market demands to create wealth (Lin, Yang, \& Arya, 2009). Entrepreneurs and managers enact strategic orientations as a catalyst to convert initial resources into capabilities and (new, improved or imitated) product-service applications (Penrose, 1959; Kor \& Mahoney, 2004). However, subsequently replenishing those resources is necessary to prevent a bottleneck to firm growth. Thus, as an organizational attribute governing the productive capacity of the firm, strategic orientations are inherently resource intensive. The RBV does not explain effectively how some new ventures are better at sourcing subsequent stocks of resources to replenish and enable profitable growth. We theorize that as a new venture burns through its initial resource stocks held at its founding, the strategic orientation entrepreneurs and managers set in place activates a search process for new resources. Commensurate with Penrosian (Penrose, 1959) logic, the new venture is motivated by the importance of continuous maintenance of its resources to protect its emerging rents and competitive advantage. However, we posit that the success of that search process depends on whether the configuration of strategic orientation(s) best suits the circumstances of its context and forms a coherent and legitimate strategic fit in the eyes of resource holders and providers, given a particular context.

Entrepreneurially oriented firms introduce new processes of production, produce new products or produce old products in new ways (Lumpkin \& Dess, 1996). New ventures are potentially more innovative than incumbents because they possess unorthodox advantages of newness (Hughes, Morgan, Ireland, \& Hughes, 2014) to combine scarce resources in more novel ways to create new products, processes, materials, or services (Hughes \& Morgan, 2007; Anokhin et al., 2011). They take more risks and aspire towards proactive market leadership (Khan and Manopichetwattana, 1989; Miller, 1983). Thus, new ventures with a strong entrepreneurial orientation bear a general tendency to embrace new and novel innovations that are ahead of the market and its competitions, and by virtue of this, carry a reasonably significant risk of costly failure. This tendency explains why EO is a resource-intensive orientation that relies on being able to restock resources from external resource holders (Hughes et al., 2015). Moreover, it is because EO can foster a series of unproductive, resource-wasteful initiatives that scholars have recently questioned whether the optimization of EO requires a second orientation focused on stability and control (Covin \& Wales, 2019). Entrepreneurial new ventures can be become viable in the short-to-medium term by 
bettering or improving products and technologies through an opportunistic orientation (OO). New ventures may profit by leveraging information asymmetry or imitation (Anokhin et al., 2010). Because emerging markets exhibit routine failures in the function of the market mechanism, a commensurate strategic posture better suited to the degree of environmental dynamism enables the firm to achieve a better fit with its environment in a way that creates legitimacy among resource holders. Since dynamic environments experience rapid changes in the supply and demand of resources, new ventures can opportunistically identify opportunities on the market side and technology side (through an OO) that are less risky than those driven by an EO. These general tendencies occur path dependently due to the attributes of each orientation.

That the resources a firm holds at any one time places a bind on its activities and the opportunities it may seize (Penrose, 1959), we reason that a particular strategic orientation will initiate a path-dependent search for new but related resource stocks to enable the new venture to continue forming and protecting its market position from imitation (EO). Where imitation instead forms the core of its strategic orientation (OO), we expect the same behavior but for an altogether different bundle of resources form an altogether different set of resource holders to EO. Both orientations would be expected to be a crucial catalyst in new venture resource acquisition. Which orientation, or a combination thereof, is best we theorize is context sensitive.

Environmental dynamism is one characteristic of the Chinese entrepreneurial environment (Goll \& Rasheed, 2004) and dynamism destabilizes the predictability of a firm's actions when environments are changeable (Ahlstrom \& Bruton, 2006). More dynamic environments are characterized by uncertainty and greater change in technology, rates of innovation and $\mathrm{R} \& \mathrm{D}$ activity. The Chinese transitional environment provides more opportunities for innovative new venture creation; but, conversely, it constitutes a significant challenge to entrepreneurs because of informality in the private sector (Batjargal, 2007). While an EO may seem desirable in such situations, this is not inherently so due to widespread opportunistic behaviors fueled by market and institutional dynamics (Li \& Zhang, 2007). New ventures often pre imitate others' innovative practices under such context (Anokhin et al., 2011) rather than solely shape their own through an EO because it may be more straightforward to extract legitimacy and profit that, in turn, may ease the acquisition of resources. The transition of information between the supply and demand for resources is inhibited when market information cannot transfer smoothly or easily. The pricing mechanism is ineffective and temporary. New ventures may then need to make use of market arbitrage opportunity (Anokhin et al., 2011) and enact an opportunistic orientation concurrent to an EO to present a business model legitimate to resource holders.

Acting on either entrepreneurial or opportunistic ambitions requires resources and resource acquisition is a vital task for new ventures. For example, the process of new venture creation and growth needs the accumulation of a variety of resource to overcome their limited financial capability (Brush, Greene, \& Hart, 2001a). Obtaining adequate resources is necessary for new ventures to pursue identified opportunities to survive, grow, and generate profits (Cai et al., 2014). Because EO is resource-intensive, that resource consumption is central to the fulfillment of their entrepreneurial ambitions (Jiang et al., 2018), and because new ventures will not have all the resources they need internally to act on valuable opportunities (Hughes et al., 2015), we expect entrepreneurially-oriented new ventures to exhibit a high motivation to seek and 
acquire external resources. This logic explains the stimulus for new ventures to acquire resources. Consistent with the RBV, we expect that the behaviors contained in EO initiate search processes and shapes stories about new ventures that assist in acquiring external resources (e.g., Martens, Jennings, \& Jennings, 2007). The environment may attenuate any such relationship by destabilizing the extent to which EO behaviors are valued alone over and above those behaviors associated with $\mathrm{OO}$, frames risk appetite among resource providers, and alters the resources available for new ventures. We expect $\mathrm{OO}$ to change any effect further because it reshapes the image and objectives of the firm in the eyes of resource holders and the nature and complexity of what resources the new venture may need when driven by individual or concurrent strategic orientations. Figure 1 illustrates our research framework. We present our formal hypotheses next.

\section{EO and resource acquisition}

EO is an organizational attribute that connects entrepreneurial behavior with firms' strategic decision-making styles, methods, and practices (Lumpkin \& Dess, 1996). Firms with EO are more likely to take risks than their peers who hold a low degree of EO. However, firms need resources to provide a cushion or insurance cover to insulate their entrepreneurial purposes from catastrophic loss (Gupta, 2019). That is, the exploratory function of EO can lead to large gains but also large losses because of the inherent uncertainty contained in risky, innovative, proactive (i.e., forward-looking) behavior (Patel, Kohtamäki, Parida, \& Wincent, 2015). EO, therefore, is a resource-consuming orientation, and it is challenging to maintain EO in small firms who have resources constraints (Gupta, 2019). In RBV terms, we expect its bias towards capitalizing on productive new opportunities will cause new ventures high (low) in EO to initiate an aggressive (constrained) search to acquire new resources (Covin \& Wales, 2019).

According to Miller (1983), although effective utilization of existing resources can leverage firms' abilities to engage risk-taking strategies proactively and generates competitive advantages against competition. Acquiring new resources (e.g., materials,

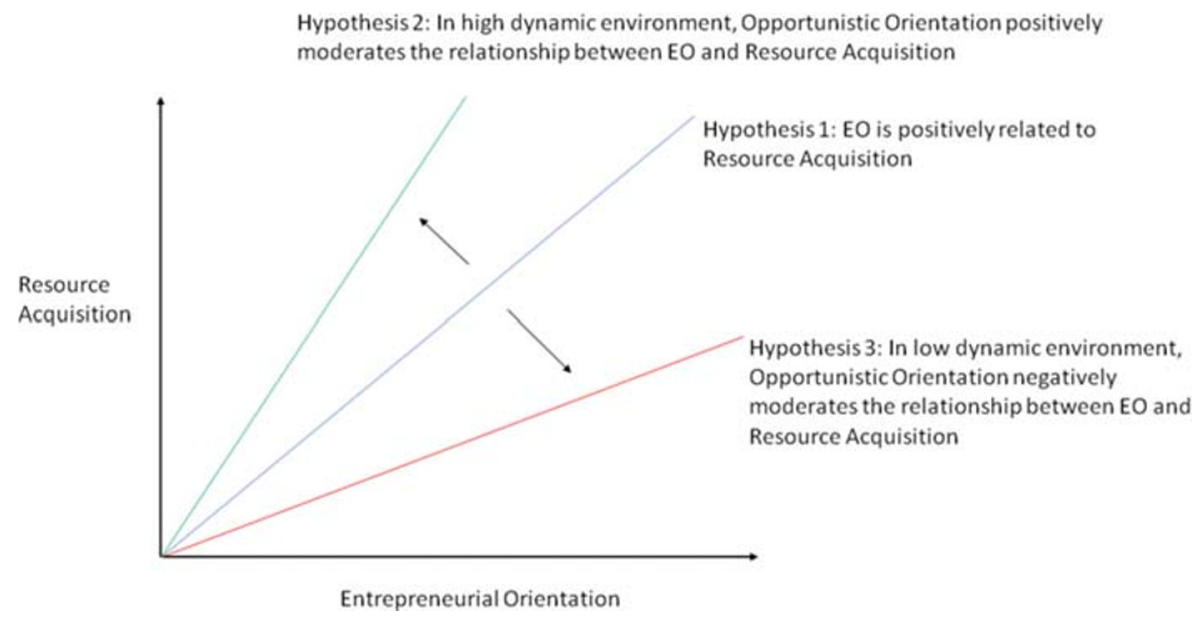

Fig. 1 Research framework 
technological resources, knowledge and skills) is a faster means than increasing the effective utilization of current resources (e.g., through training). Reconfiguring existing resources rarely assist firms in fitting to market requirements, particularly for entrepreneurial firms (Le Mens, Hannan, \& Polos, 2015). Relying on existing resources limit the productive opportunity set of the entrepreneurial-oriented new venture and eventually risk capabilities becoming outdated rigidities. When new ventures hold a high degree of EO, these firms are more likely to seek and acquire resources which help them to seize sensed business opportunities and initiate a new wave of entrepreneurial actions (Covin \& Slevin, 1991; Wales, Patel, Parida, \& Kreiser, 2013; Hughes et al., 2015). Conversely, new ventures with low EO are more likely to come across as unambitious and conservative to resource holders who are subsequently more likely to perceive low growth projections. With a low degree of EO, new ventures are unlikely to sense and seize truly new opportunities in a business environment for high-margin growth. In response, the pool of resource providers shrinks for such firms in comparison to those led by EO. In summary, then, we expect:

H1. Entrepreneurial orientation has a positive effect on resource acquisition among new ventures.

\section{0, EO, and resource acquisition in different environment contexts}

Environmental dynamism is not consistent across China. In a highly dynamic environment, the preferences of customers change quickly, which shortens the life cycle of products and services (Lee \& Chu, 2013). To maintain market position, new ventures must create a close fit between the products/services they offer and customers' tastes (Venkatraman \& Camillus, 1984). Firms with a high level of EO behave proactively in sensing business opportunities and seizing these opportunities with support from resources accumulated from continuous new resources acquisition (Lee \& Chu, 2013). In RBV terms, productive opportunities are those that enable the new venture to act on emerging technologies and tastes to form defendable competitive positions, and EO will initiate a search process for such resources as a way to protect its emerging rents and competitive advantage.

However, it is challenging to predict customers' preferences when environmental dynamism is extremely high and, ergo, challenging to predict which combination of opportunities and entrepreneurial actions will generate profitable breakthrough technological advances (e.g., Doorn, Heyden, \& Volberda, 2017). Many firms in China face these conditions, and such business markets generate uncertainties between the new products/services created by firms driven by an EO and the true preferences of customers. In such situations, innovation investments driven by EO are more likely to create failure traps in which exploratory investments fail and to rebound, even more entrepreneurial exploration is initiated. The risk is that new ventures burn resources more quickly and, while that initiates a search for more resources, an entrepreneurial strategy will appear increasingly less compelling to resource holders if the new venture does not evidence a return. That is, the search for resources is not allied to a compelling narrative for sustainability necessary to elicit resources from resource holders. A 
highly dynamic environment causes new ventures to enter a dilemma of how best to create a compelling proposition to resource holders, therefore.

These uncertainties can promote OO to marry EO with arbitrage behavior (Koberg, Detienne, \& Heppard, 2003; Chan, Yee, Dai, \& Lim, 2016). A newer venture exhibiting an $\mathrm{OO}$ within a highly dynamic environment could reduce concerns among resource holders by lowering the cost and difficulty of acquiring resources and selling products at a high price, and by securing short-to-medium term revenues that offset exploratory costs and losses from EO. That is, new ventures acting with high OO can imitate existing technology (Anokhin \& Wincent, 2014) to support their EO initiatives and strategies when environmental dynamism is high. In China, this is a common strategy because, within a highly dynamic environment, information is asymmetric ( $\mathrm{Li}$ \& Liu, 2014), OO fosters new ventures to make use of asymmetry information in order to reduce cost (Anokhin et al., 2010). This directs new ventures to scan the environment to seek resources from a different (and broader) pool of resources than would otherwise be the case solely with an EO strategy. Because the combination of EO and OO should create a more compelling strategic fit under high environmental dynamism, resource holders are more likely to make available resources to the new venture. Therefore:

H2. In a highly dynamic environment, OO positively moderates the relationship between $\mathrm{EO}$ and resource acquisition.

In other parts of China, firms encounter relatively lower environmental dynamism. When environmental dynamism is low, industry boundaries are clearer, industry recipes are stable for a longer time, anticipating market demand is possible, and the probability of environmental shock is low (Doorn et al., 2017). In these circumstances, resource holders will likely prioritize resources to those new ventures with a clear pathway to exploiting the most productive opportunities. In the RBV, new ventures form because they provide a more productive solution to the utilization of resources for wealth creation (Barney, 1991; Barney et al., 2001). New ventures with EO still consume resources to take risky actions, and proactively occupy markets (Jiang et al., 2018; Wiklund \& Shepherd, 2005). However, the merits of adding an OO to the entrepreneurially oriented new venture will likely be different than those when environmental dynamism is high.

A low dynamic environment fosters stepwise improvement of current products and services (Koberg et al., 2003). Cost reduction is encouraged at the expense of EO because markets rarely change in tumultuous ways when environmental dynamism is low. These orientations become substitutive rather than complementary under this condition. In this situation, $\mathrm{OO}$ in new ventures would inhibit the effect of EO on resource acquisition because both holding strategic orientations simultaneously is unnecessary to maintain strategic fit, and doing so should cause confusion about strategy coherence among resource holders (e.g., Hughes \& Morgan, 2008). Under a low dynamic environment, imitation can consume fewer resources because imitation aims to reduce cost (Anokhin \& Wincent, 2014). This depletes the motivation to seek new resources. Also, because change is slow and returns to imitated products and services are stable, there is less of a need to engage in resource-hungry activities such as EO. Perversely, though, when environmental dynamism is low, a new venture prioritizing a high level of $\mathrm{OO}$ could be disadvantaged by a difficulty in generating unique 
information about their venture (Anokhin et al., 2010) because information is easily transferred and market information is more symmetric. This inhibits firms with high EO to acquire resources and weakens the relationship between EO and resource acquisition. Thus:

H3. In a low dynamic environment, OO negatively moderates the relationship between $\mathrm{EO}$ and resource acquisition.

\section{Method}

\section{Data}

To test these hypotheses, we surveyed new ventures in China from March to June 2017. Following the extant literature, we defined new ventures as younger than eight years old (Bamford, Dean, \& Douglas, 2004; Li \& Zhang, 2007). The sampling frame was drawn from three regions of China: Jilin province, Guangzhou province and the megacity of Beijing. Guangzhou and Beijing represent locations with a high entrepreneurial active index, and Jilin Province represents areas with a low entrepreneurial active index, according to the Global Entrepreneurship Monitor (Gao, 2006; see also Li \& Liu, 2014; Zheng \& Zhao, 2017; Zhou \& Li, 2010). Our sample accounts for variance in the intensity of entrepreneurial activities in those regions to ensure that environmental dynamism is captured in our sample frame. All the samples are from four primary industries, manufacturing, retailing, general service, and IT service, to provide a degree of generalizability to the results of our study. Before the formal survey, we carried out a pilot survey with 15 entrepreneurs (please see the Measures subsection for specific information on the application of this procedure). The final questionnaire was mailed to 1000 randomly selected entrepreneurs (500 in Jilin province, 200 in Guangzhou province, and 300 in Beijing). In total, 361 usable questionnaires were returned for a response rate of $36.1 \%$, which is comparable to similar studies conducted in China. Respondents were assured of their anonymity.

We examined non-response bias by comparing late respondents to early respondents (Armstrong \& Overton, 1977). First, we split the sample into two parts according to the date on which each firm's questionnaire was received. In total, 176 firms were early responders, and 183 firms were late responders. Then we used T-tests to compare the independent variables, moderator variables and dependent variables of the two groups. Results show that there were no statistically significant differences $(p>.05)$ on the two groups. Further, we compared the demographic profiles (such as industry, age of firm and number of employees) (Rogelberg \& Stanton, 2007). The results show that the observed of the late respondents were not significantly different from those of the early respondents. Thus, we conclude that non-response bias does not appear to be a significant threat in this study.

We describe the sample characteristics in Table $1.43 .35 \%$ of the sample was comprised of new ventures less than 3 years old, and the remaining new ventures were between 4 and 8 years old at the time of data collection. Similarly, concerning firm size, about $57.9 \%$ of new ventures employed fewer than 20 individuals, about $24.7 \%$ of new 
Table 1 Description of sample

\begin{tabular}{llll}
\hline Characteristics & Measurements & Sample & Percentage(\%) \\
\hline Firms age & $0-3$ years & 114 & 43.35 \\
& $4-8$ years & 149 & 56.65 \\
Number of employees & $1-20$ persons & 150 & 57.9 \\
& $21-50$ persons & 64 & 24.7 \\
& $51-200$ persons & 33 & 12.7 \\
& 201-500 persons & 7 & 2.7 \\
501-1000 persons & 1 & 0.4 \\
Industry & 1000 above & 4 & 1.5 \\
& IT service & 112 & 42.59 \\
& Retailing & 33 & 12.55 \\
& Manufacturing & 55 & 20.91 \\
& General service & 16 & 6.08 \\
& Others & 47 & 17.87 \\
\hline
\end{tabular}

ventures had between 21 and 50 employees, $12.7 \%$ firms had between 51 and 200 employees, and less than $10 \%$ of new ventures had more than 200 employees. According to Cai et al. (2014), these statistics are consistent with new ventures more broadly in China. Finally, the distribution of new ventures in the selected industries was reasonably balanced with $42.59 \%$ of the respondents representing IT services, $12.55 \%$ representing the retailing industry, $20.91 \%$ representing manufacturing industries, $6.08 \%$ of firms representing general service industry, and the remaining firms are uncategorized. Most (52.35\%) new ventures are from Jilin province, $21.33 \%$ are from Guangzhou province, and the remainders are from Beijing.

\section{Measures}

Dependent variable We followed Cai et al. (2014) to operationalize resource acquisition. We used a 7-point Likert scale to assess how new ventures purchase resources from factor markets, attract resources from informal relationships such as friends and cooperative partners and develop resources internally. The variable demonstrates high reliability as both Cronbach alpha (.794), and composite reliability (.84) exceed the suggested cut-off of .70 (Fornell \& Larcker, 1981).

Independent, moderator and control variables Entrepreneurial orientation was measured with items based on Covin and Slevin (1989) and Green, Covin, and Slevin (2008). We used a 7-point Likert scale to capture the extent to which the company innovates, takes risks, and takes proactive actions. Cronbach alpha equaled .883, and composite reliability was .9 , indicating acceptable fit. Opportunistic orientation was measured with a 7-point Likert scale using items proposed by Anokhin et al. (2011). In particular, we captured the extent to which the company imitates new technology from other companies and seeks profits through asymmetric market information. Reliability indicators were again acceptable (Cronbach alpha $=.857$, composite reliability $=.87$ ). 
We measured environmental dynamism based on the Miller (1987) instrument that detects the speed at which core products in the industry are replaced, the rate of innovation in the industry, the speed of market change, and the difficulty in predicting competitors' behavior and customers' needs. Cronbach alpha equaled .814, and composite reliability equaled .84 , suggesting acceptable fit.

To address potential confounding effects, we select three kinds of control variables. First, firm age may influence resource acquisition behaviors. Usually, the younger the firm, the more resources they need (Cai et al., 2014) because as a firm grow older, they tend to accumulate abundant resources internally (Hughes et al., 2018a, b). In addition, EO may play different roles under different periods of firm age, for example, EO may have a positive effect on firm performance at the embryonic stage of firm growth (Hughes \& Morgan, 2007), while EO may have a nonlinear effect on firm performance at the late stage of firm growth (Wales et al., 2013). Second, firm size can also affect resource acquisition. For example, large size firm can indicate firms with greater reputation, which is helpful for attracting resources (Cai et al., 2014). Finally, we controlled for IT service, retailing, manufacturing and general service industry because new ventures in those kinds of industries are more dependent on resource integration to get a competitive advantage (Cai, Anokhin, Yin, \& Hatfield, 2016). Thus, new ventures in the above industries are more likely to acquire resources. Therefore, we need control for those industries.

Information about each of the variables and their measurements are presented in Table 2. The reliability of all variables is also included in Table 2. Table 2 also reports the inter-rater reliability in terms of "Alpha if Item Deleted".

Assessing the validity of the measurement model We assessed the validity of our measurement model in three ways. First, to enhance content validity, we discussed our constructs with 15 leading entrepreneurs and 8 professors in this research field. We asked them if they understood the concept and connotation regarding our core variables of entrepreneurial orientation, opportunistic orientation, resource acquisition and environmental dynamism. We also invited them to describe those constructs in practice or in theory according to their knowledge. Further, we pilot-tested the survey with them. We received suggestions on how to improve our semantic expression about the measurements. Second, we estimated convergent validity by reviewing the t-tests for the factor loadings (Chiu, Chien, Lin, \& Hsiao, 2005). Results show that all factor loadings for the indicators measuring the same construct were statistically significant (Anderson \& Gerbing, 1988). This is evidence supporting the measure's convergent validity (the lowest $t$-value was 10.76 , substantially larger than the cut-off value of 1.96). Third, we examined the discriminant validity of the factors using the procedures suggested by Fornell and Larcker (1981). Table 3 demonstrates that the square root of the average variance extracted (AVE) of each factor (in bold on the diagonal of Table 3 ) is larger than the correlation coefficient of that factor with other factors in the model. This suggests that all factors in the measurement models possess strong discriminant validity. Aggregating all aspects of the model evaluation, we conclude that there exists sufficient evidence of content validity, convergent validity, and discriminant validity.

Common method variance Bias due to common method variance is possible, but not inevitable, when relying on surveys as a method for data collection (Spector, 2006). To 
Table 2 Reliability of variables

\begin{tabular}{lllll}
\hline Measurements & Scale Mean & Scale & Corrected Cronbach's & Crom \\
& if Item & Variance if & Item-Total Alpha if Item \\
& Deleted & $\begin{array}{l}\text { Item } \\
\text { Deleted }\end{array}$ & Correlation Deleted \\
& & & \\
\hline
\end{tabular}

Resource acquisition: Cronbach Alpha $=.794, \mathrm{~N}$ of Items $=9$, Valid cases $=338$

(RA1) Your company purchases workshop, equipment, patent or technology and so on from factor markets

(RA2) Your company employs experienced staff from outside

(RA3) Use external financing to get capital

39.756

0.482

0.774

39.824

47.867

0.585

39.916

47.031

0.590

(RA4) Your company utilizes business plan to get

49.826

0.484 so on

(RA5) Your company utilizes reputation to get capital and 39.874 so on

(RA6) Your company utilizes description of business prospects to get workshop, equipment, technology resources, staff and so on

(RA7) Your company develops patent, technology and so 39.697

$\begin{array}{lll}50.128 & 0.489 & 0.774\end{array}$
on inside the firm

(RA8) Your company accumulates capital inside the firm

0.354

(RA9) Your company trains experienced staff inside the 40.303

Entrepreneurial orientation: Cronbach Alpha $=.883, \mathrm{~N}$ of Items $=9$, Valid cases $=341$

(EO1) Your company emphasis on R\&D, technological leadership and innovation

$\begin{array}{lll}32.499 & 0.635 & 0.869 \\ 32.577 & 0.615 & 0.871 \\ 32.036 & 0.674 & 0.866 \\ 33.857 & 0.493 & 0.881 \\ & & \\ 32.775 & 0.608 & 0.872\end{array}$

(EO5) Your company is the first business to introduce new products/services, administrative techniques, operating technologies, etc.

(EO6) In dealing with its competitors, your company typically adopts a competitive, "undo the-competitors" posture

(EO7) Your company has a strong proclivity for high risk projects (with chances of very high returns)

(EO8) Owing to the nature of the environment, bold, wide-ranging acts are necessary to for your company to achieve the firm's objectives

(EO9) Your company typically adopts a bold, aggressive $\quad-0.339$ posture in order to maximize the probability of exploiting potential opportunities

Opportunistic orientation: Cronbach Alpha $=.857, \mathrm{~N}$ of Items $=9$, Valid cases $=343$

(OO1) Your company invests resources to once it is clear that the market has accepted them 
Table 2 (continued)

\begin{tabular}{|c|c|c|c|c|}
\hline Measurements & $\begin{array}{l}\text { Scale Mean } \\
\text { if Item } \\
\text { Deleted }\end{array}$ & $\begin{array}{l}\text { Scale } \\
\text { Variance if } \\
\text { Item } \\
\text { Deleted }\end{array}$ & $\begin{array}{l}\text { Corrected } \\
\text { Item-Total } \\
\text { Correlation }\end{array}$ & $\begin{array}{l}\text { Cronbach's } \\
\text { Alpha if Item } \\
\text { Deleted }\end{array}$ \\
\hline $\begin{array}{l}\text { (OO2) Your company closely monitors other firms in our } \\
\text { industry to find benchmarks they can learn from }\end{array}$ & -.089 & 29.730 & .601 & .840 \\
\hline $\begin{array}{l}\text { (OO3) Your company carefully studies industry leaders to } \\
\text { understand and adopt their organization practices }\end{array}$ & -.112 & 29.701 & .611 & .839 \\
\hline $\begin{array}{l}\text { (OO4) Your company tries to minimize risks even if it } \\
\text { means shorter-term and modest but more certain } \\
\text { returns - such as efficiently producing established } \\
\text { products that are still demanded by the market }\end{array}$ & -.107 & 30.037 & .572 & .843 \\
\hline $\begin{array}{l}\text { (OO5) Is your company proactive in seeking legal help to } \\
\text { "invent around" high-potential products launched by } \\
\text { others }\end{array}$ & -.086 & 29.460 & .625 & .837 \\
\hline $\begin{array}{l}\text { (OO6) Your company insists that because of limited } \\
\text { resources, scattering attention to other countries, } \\
\text { markets or industries may be wasteful }\end{array}$ & -.108 & 30.239 & .551 & .845 \\
\hline $\begin{array}{l}\text { (OO7) Your company pays attention to changes in } \\
\text { consumer preferences over time to capitalize on } \\
\text { emerging trends }\end{array}$ & -.076 & 28.945 & .678 & .832 \\
\hline $\begin{array}{l}\text { (OO8) Your company looks for new uses of our firm's } \\
\text { capabilities in other markets and/or industries }\end{array}$ & -.093 & 29.230 & .642 & .836 \\
\hline $\begin{array}{l}\text { (OO9) Your company prefers to build on existing } \\
\text { relationships within tested markets and industries } \\
\text { rather than follow rivals' lead into new ones }\end{array}$ & -.117 & 31.124 & .469 & .853 \\
\hline \multicolumn{5}{|l|}{$\begin{array}{l}\text { Environmental dynamism: Cronbach Alpha }=.798, \mathrm{~N} \\
\text { of Items }=4 \text {, Valid cases }=358\end{array}$} \\
\hline $\begin{array}{l}\text { (DE 1) Growth opportunities in the environment have } \\
\text { increased dramatically over the past } 5 \text { years }\end{array}$ & 15.341 & 12.724 & .463 & .817 \\
\hline $\begin{array}{l}\text { (DE 2) Production/service technology in your principal } \\
\text { industry has changed very much over the past } 5 \text { years }\end{array}$ & 14.957 & 10.983 & .688 & .709 \\
\hline $\begin{array}{l}\text { (DE 3) Rate of innovation of new operating processes and } \\
\text { new products or services in your principal industry has } \\
\text { dramatically increased over the past } 5 \text { years }\end{array}$ & 14.984 & 11.152 & 0.681 & 0.713 \\
\hline $\begin{array}{l}\text { (DE 4) Research and development }(\mathrm{R} \& \mathrm{D}) \text { activity in your } \\
\text { principal industry has substantially over the past } \\
5 \text { years }\end{array}$ & 15.159 & 11.115 & 0.620 & 0.743 \\
\hline
\end{tabular}

reduce the danger of common method bias, we adapted certain aspects of survey design before collecting data (e.g., Podsakoff, MacKenzie, \& Podsakoff, 2012; Podsakoff, MacKenzie, Lee, \& Podsakoff, 2003). First, we made the items easy to read and clear to understand (Peterson, 2000). Moreover, we eliminated ambiguity in the wording of items and analyzed item wording to ensure the scales were fully comprehensible. Second, we restricted the use of items to reduce the possibility of respondent fatigue in completing the questionnaire, and considered the influence of previously-answered items (Min, Park, \& Kim, 2016; Peterson, 2000). Third, we reduced the effect of measurement context by changing the time, location, and media during data collecting (Min et al., 2016). Fourth, we assured and protected respondent anonymity to eliminate evaluation apprehension and any incentive among respondents to provide answers that might be perceived as desirable or positive. 
After data collection, we used two methods to test for the possibility of common method variance. First, we used the Harman one-factor test (Podsakoff et al., 2003). The un-rotated exploratory factor analysis did not yield a single-factor structure. Moreover, the independent variables and the dependent variable do not load onto the same factor. This indicates that common method variance is not a serious concern. Furthermore, the first factor only explained $27.77 \%$ of variance among our variables. Second, we used the unmeasured latent factor technique to further test for common method variance (Podsakoff et al., 2012). After adding one factor that represents a common method variance to the four-factor model $(\mathrm{GFI}=.75, \mathrm{AGFI}=.71, \mathrm{CFI}=.784$, $\mathrm{TLI}=.766$, RMSEA $=.089)$, we saw little change in model fit $(\mathrm{GFI}=.754$, AGFI $=$ $.71, \mathrm{CFI}=.791, \mathrm{TLI}=.722$, RMSEA $=.088$ ). Therefore, common method bias is absent and highly unlikely to explain any of our results.

\section{Results}

\section{Hypothesis examination}

From Table 3 we can see that there are correlations among EO, OO, and resource acquisition that partly support our hypothesis. To deepen our analysis about the relationship between EO and resource acquisition, and the moderating effect of $\mathrm{OO}$ under high dynamic environment and low dynamic environment. To treat the level of environmental dynamism, we divided the entire dataset into two groups. Specifically, we calculated the mean value of environmental dynamism, and then took 4 as the cutoff point to divide the sample into two parts, in which the highly dynamic environment group is higher than 4 and the weakly dynamic environment group is lower than 4 .

To examine the hypotheses, we use the SPSS16.0 software and adopt regression analysis. First, we analyzed the data under the condition of high dynamic environment, and the results are shown in Table 4. In model 1, we control for firm age, firm size and industry (IT service, retailing, manufacturing and general service) and results show that these have no bearing on resource acquisition. In model 2, we see that EO has a positive effect on resource acquisition $(\beta=.395, P<.01)$. In model 3 , we introduce the variable OO. Results show that $\mathrm{OO}$ positively influences resource acquisition $(\beta=.33, \mathrm{P}<.01)$.

Table 3 Descriptive statistics and correlations

\begin{tabular}{|c|c|c|c|c|c|c|}
\hline Variables & Mean & $\begin{array}{l}\text { Std. } \\
\text { Deviation }\end{array}$ & $\mathrm{EO}$ & $\mathrm{OO}$ & $\begin{array}{l}\text { Resource } \\
\text { acquisition }\end{array}$ & $\begin{array}{l}\text { Environmental } \\
\text { dynamism }\end{array}$ \\
\hline EO & 4.804 & .906 & .707 & & & \\
\hline $\mathrm{OO}$ & 4.666 & 1.033 & $.702 * *$ & .648 & & \\
\hline Resource acquisition & 4.924 & .830 & $.456 * *$ & $.514 * *$ & .624 & \\
\hline $\begin{array}{c}\text { Environmental } \\
\text { dynamism }\end{array}$ & 5.037 & 1.094 & $.586^{* *}$ & $.58 * *$ & $.407 * *$ & .757 \\
\hline
\end{tabular}

$* p<.05 ; * * p<.01$. Numbers in bold represent the square root of the average variance extracted (AVE) 
In model 4, we examined the moderating effect of OO. However, the results do not support Hypothesis $2(\beta=-.084, P>.1)$.

To test whether an increment in the proportion of variance accounted for by model modification adds value, we use an F-test. We examined for a significant change in the square of the multiple correlation coefficient. As shown in Table 4, the increase of $\mathrm{R}^{2}$ from Model 1 to Model 2 is .148 , the increase of $\mathrm{R}^{2}$ from Model 2 to Model 3 is .067 , and the increase of $\mathrm{R}^{2}$ from Model 3 to Model 4 is .006. This data suggests that our model fits well and bears explanatory power that improves with each iteration.

Second, we analyzed the data under the condition of a low dynamic environment. The results are shown in Table 5. In model 1, we controlled firm age, firm size and industry (IT service, retailing, manufacturing and general service) and the results show that firm age $(\beta=.155, P<.1)$, firm size $(\beta=.409, \mathrm{P}<.01)$ and general service industry $(\beta=.157, P<.05)$ influence resource acquisition. In model 2 , we see that EO has a positive effect on resource acquisition $(\beta=.368, \mathrm{P}<.01)$. Considered together with the results shown in Table 3 for high dynamic environment, these results in total mean that Hypothesis 1 predicts the positive effect of EO on resource acquisition is supported. In model 3, we introduced the variable OO. Results show that OO positively influences resource acquisition $(\beta=.420, \mathrm{P}<.01)$ once more. In model 4 , we examined the moderating effect of $\mathrm{OO}$ and the results support Hypothesis 3 ( $\beta=-.148$, $\mathrm{P}<.1)$.

From Table 5, the increase of $\mathrm{R}^{2}$ from Model 1 to Model 2 is .137, the increase of $\mathrm{R}^{2}$ from Model 2 to Model 3 is .088, the increase of $\mathrm{R}^{2}$ from Model 3 to Model 4 is .011 . This suggests our model fits well in this instance too, and our model also bears explanatory power that increases with each iteration.

Table 4 Relationships among EO, OO and resource acquisition under high dynamic environment

\begin{tabular}{|c|c|c|c|c|}
\hline \multirow[t]{2}{*}{ Explaining variables } & \multicolumn{4}{|c|}{ Explained variables:resource acquisition } \\
\hline & M 1 & M 2 & M 3 & M 4 \\
\hline Firm age & -.143 & $-.147 \dagger$ & $-.15 \dagger$ & $-.155 \dagger$ \\
\hline Firm size & .025 & .054 & .052 & .041 \\
\hline IT service & .054 & .174 & .182 & .191 \\
\hline Retailing & -.050 & -.009 & .002 & .008 \\
\hline Manufacturing & .117 & .170 & .191 & .193 \\
\hline General service & .101 & $.196 \dagger$ & $.197 \dagger$ & $.214 \dagger$ \\
\hline $\mathrm{EO}$ & & $.395 * *$ & $.192 \dagger$ & $.222 *$ \\
\hline $\mathrm{OO}$ & & & $.330^{* * *}$ & $.338^{*}$ \\
\hline $\mathrm{EO} * \mathrm{OO}$ & & & & -.084 \\
\hline $\mathrm{R}^{2}$ & .04 & .188 & .255 & .261 \\
\hline Adjusted R² & -.011 & .137 & .202 & .2 \\
\hline$\Delta \mathrm{R}^{2}$ & & .148 & .067 & .006 \\
\hline F-value & .785 & $20.375^{* *}$ & $10.059 * *$ & .827 \\
\hline
\end{tabular}

$\dagger p<.10 ; * p<.05 ; * * p<.01$ 
Table 5 Relationships among EO, OO and resource acquisition under low dynamic environment

\begin{tabular}{lllll}
\hline Explaining variables & \multicolumn{2}{l}{ Explained variables:resource acquisition } & & \\
\cline { 2 - 5 } & $\mathrm{M} 1$ & $\mathrm{M} 2$ & $\mathrm{M} \mathrm{3}$ & $\mathrm{M} 4$ \\
\hline Firm age & $.155^{\dagger}$ & .118 & $.134 \dagger$ & .120 \\
Firm size & $.409^{* *}$ & $.412^{* *}$ & $.389^{* *}$ & $.379^{* *}$ \\
IT service & -.130 & -.099 & -.092 & -.124 \\
Retailing & -.101 & -.031 & -.009 & -.025 \\
Manufacturing & -.009 & -.047 & -.013 & -.037 \\
General service & $.157^{*}$ & $.179^{*}$ & $.153^{*}$ & $.139 \dagger$ \\
EO & & $.368^{* *}$ & .085 & .026 \\
OO & & & $.420^{* *}$ & $.370^{* *}$ \\
EO $*$ OO & & & & $-.148 \dagger$ \\
$\mathrm{R}^{2}$ & .182 & .319 & .407 & .417 \\
Adjusted $\mathrm{R}^{2}$ & .149 & .286 & .374 & .381 \\
$\Delta \mathrm{R}^{2}$ & & .137 & .088 & .011 \\
F-value & $5.488^{* *}$ & $29.46^{* *}$ & 21.694 & $2.673 \dagger$ \\
\hline
\end{tabular}

$\dagger p<.10 ; * p<.05 ; * * p<.01$

\section{Robustness tests}

To confirm our results, we performed a robustness check analyzing the relationship between EO and resource acquisition under four contexts, which includes high dynamic environment and low OO, high dynamic environment and high OO, low dynamic environment and high OO, and low dynamic environment and low OO. The results are summarized in Table 6. We used SEM to examine the relationship between EO and resource acquisition by dividing the sample data into four groups. By comparing Group 1 and Group 2, the path coefficient between EO and resource acquisition changes from non-significant to significant and positive $(.486$ versus $.523, \chi 2 /$ d.f. $=3.92, \mathrm{RMR}=.05$, $\mathrm{GFI}=.91, \mathrm{NFI}=.93, \mathrm{PGFI}=.51$, RMSEA $=.08)$. This result supports Hypothesis 2. By comparing Group 3 and Group 4, the path coefficient between EO and resource acquisition changes from high to low, both significant $(.69$ versus $.402, \chi 2 /$ d.f. $=3.92$, $\mathrm{RMR}=.05, \mathrm{GFI}=.91, \mathrm{NFI}=.93, \mathrm{PGFI}=.51$, RMSEA $=.08)$, which support our Hypothesis 3. Results of the four groups support Hypothesis 1.

\section{Endogeneity tests}

Bidirectional causality, missing variables, and self-selection bias may lead to endogenous problems. In order to eliminate endogenous interference, the following endogenous test was conducted. First, in order to reduce the observation error caused by missing variables, we add the logarithm of firm's capital as a control variable to test for missing variables. Table 7 shows that after adding capital as a control variable, EO still positively influences resource acquisition at .01 significance level, and the interaction of EO and $\mathrm{OO}$ still positively influences resource acquisition at the .01 significant level 
Table 6 Robustness test

\begin{tabular}{|c|c|c|c|c|c|}
\hline & Path description & $\begin{array}{l}\text { Group } 1 \\
\text { (high dynamic } \\
\text { environment, } \\
\text { low OO) }\end{array}$ & $\begin{array}{l}\text { Group } 2 \\
\text { (high dynamic } \\
\text { environment } \\
\text { high OO) }\end{array}$ & $\begin{array}{l}\text { Group } 3 \\
\text { (low dynamic } \\
\text { environment, } \\
\text { low OO) }\end{array}$ & $\begin{array}{l}\text { Group } 4 \\
\text { (low dynamic } \\
\text { environment, } \\
\text { high OO) }\end{array}$ \\
\hline & & Coefficient $(\beta)$ & Coefficient $(\beta)$ & Coefficient $(\beta)$ & Coefficient $(\beta)$ \\
\hline $\begin{array}{c}\text { Regression } \\
\text { weights }\end{array}$ & $\begin{array}{c}\mathrm{EO} \rightarrow \text { resource } \\
\text { acquisition }\end{array}$ & .486 & $.523 *$ & $.69 * *$ & $.402^{* *}$ \\
\hline parameters & \multicolumn{5}{|c|}{$\chi 2 /$ d.f. $=3.92, \mathrm{RMR}=.05, \mathrm{GFI}=.91, \mathrm{NFI}=.93, \mathrm{PGFI}=.51, \mathrm{RMSEA}=.08$} \\
\hline
\end{tabular}

$\dagger p<.10 ; * p<.05 ; * * p<.01$

under high dynamic environment. Table 10 shows that after adding capital as a control variable, EO still positively influences resource acquisition at the .01 significance level; $\mathrm{OO}$ negatively influences resource acquisition, but the interaction of $\mathrm{EO}$ and $\mathrm{OO}$ has no significant effect on resource acquisition under low dynamic environment. Second, we use Heckman Second-Stage test to examine self-selection bias. The results show that the coefficients of Inverse Mills Ratio lack statistical significance in all the second-stage regressions indicates the absence of self-selection bias (see Table 9 and Table 12). Third, this research use instrument variable (IV) entrepreneurial experience to further examine for endogeneity. Table 8 shows that after controlling for endogeneity, EO still positively influences resource acquisition, and the interaction between $\mathrm{EO}$ and $\mathrm{OO}$ is also positively influencing resource acquisition under high dynamic environment. Table 11 shows that after controlling endogeneity, EO still positively influences

Table 7 Add control variables that may be missing under high dynamic environment

\begin{tabular}{lllll}
\hline Explaining variables & \multicolumn{3}{l}{ Explained variable:resource acquisition } & \\
\cline { 2 - 5 } & $\mathrm{M} 1$ & $\mathrm{M} 2$ & $\mathrm{M} \mathrm{3}$ & $\mathrm{M} 4$ \\
\hline Firm age & .001 & .001 & .001 & .001 \\
Firm size & -.086 & -.071 & -.089 & -.073 \\
IT service & .219 & .171 & .254 & .229 \\
Retailing & .192 & .156 & .282 & .190 \\
Manufacturing & .115 & -.015 & .151 & .067 \\
General service & .784 & .786 & $.821 \dagger$ & .782 \\
Capital & .011 & .013 & .012 & .020 \\
EO & & $.285^{* *}$ & & $.092^{* *}$ \\
OO & & & .205 & .054 \\
EO * OO & .213 & .100 & .036 & $.036^{* *}$ \\
$\mathrm{R}^{2}$ & -.013 & .064 & .018 & .065 \\
Adjusted $\mathrm{R}^{2}$ & & -.113 & .003 & .007 \\
$\Delta \mathrm{R}^{2}$ & .62 & $2.76^{* *}$ & $1.47^{* *}$ & $2.42^{* *}$ \\
F-value & &
\end{tabular}

$\dagger p<.10 ; * p<.05 ; * * p<.01$ 
Table 8 Endogeneity test: entrepreneurial experience instrumental variable test under high dynamic environment

\begin{tabular}{llll}
\hline Explaining variables & \multicolumn{2}{l}{ Explained variable:resource acquisition } & \\
\cline { 2 - 4 } Controls & Yes & Yes & Yes \\
\hline EO & $.1124 * *$ & & \\
OO & & 13.896 & $.2223^{*}$ \\
EO $*$ OO & & & .005 \\
Partial R & .010 & .000 & $1.091^{* *}$ \\
Partial R $2: F$ & $20.84 * *$ & $.016^{* *}$ & $4.058^{*}$ \\
Hausman test & $4.493^{* *}$ & $2.599 \dagger$ & .000 \\
Adj- R & .005 & -.005 & 207 \\
Observations & 207 & 207 & 207 \\
\hline
\end{tabular}

$\dagger p<.10 ; * p<.05 ; * * p<.01$

resource acquisition, but the interaction between $\mathrm{EO}$ and $\mathrm{OO}$ is not significantly influencing resource acquisition under low dynamic environment. In conclusion, the Hausman test rejects the null hypothesis without endogeneity.

We plot the relationships among EO, OO, and resource acquisition under low dynamic environment in Fig. 2.

\section{Discussion}

This study examines the often speculated but rarely theorized or tested relationship between EO and new venture resource acquisition. Drawing on the RBV, we theorize the resource consumption intensity of EO, coupled with its bias towards risky,

Table 9 Endogeneity test: Heckman second-stage test under high dynamic environment

\begin{tabular}{llll}
\hline Explaining variables & \multicolumn{2}{l}{ Explained variable:resource acquisition } \\
\hline Firm age & .033 & .001 & .001 \\
Firm size & .295 & -.025 & -.016 \\
IT service & .000 & .285 & $.524 \dagger$ \\
Retailing & .000 & .662 & $.803 \dagger$ \\
Manufacturing & .000 & .157 & .441 \\
General service & .000 & .998 & 1.072 \\
Inverse Mills Ratio & .000 & -1.249 & -.205 \\
EO & & $.467^{* *}$ & -.331 \\
EO $*$ OO & & & $.104^{* *}$ \\
Wald chi2 & 1.74 & $21.83^{* *}$ & $30.36^{* *}$ \\
Prob $>$ chi2 & .419 & .003 & .000 \\
\hline
\end{tabular}

$\dagger p<.10 ; * p<.05 ; * * p<.01$ 
Table 10 Additional control variables that may be missing under low dynamic environment

\begin{tabular}{|c|c|c|c|c|}
\hline \multirow[t]{2}{*}{ Explaining variables } & \multicolumn{4}{|c|}{ Explained variable:resource acquisition } \\
\hline & M 1 & M 2 & M 3 & M 4 \\
\hline Firm age & -.038 & $-.043 \dagger$ & -.034 & $-.045 \dagger$ \\
\hline Firm size & .133 & $.199 \dagger$ & .160 & $.223 *$ \\
\hline IT service & -.206 & -.383 & -.225 & -.351 \\
\hline Retailing & $-.867^{*}$ & $-.978^{*}$ & $-.866 \dagger$ & $-.953 *$ \\
\hline Manufacturing & .117 & -.174 & .120 & -.172 \\
\hline General service & -.171 & -.225 & -.318 & -.192 \\
\hline Capital & .068 & .034 & .034 & .026 \\
\hline EO & & $.383^{* *}$ & & .154 \\
\hline $\mathrm{OO}$ & & & .191 & $-.209^{*}$ \\
\hline $\mathrm{EO} * \mathrm{OO}$ & & & & .064 \\
\hline $\mathrm{R}^{2}$ & .087 & .180 & .110 & .190 \\
\hline Adjusted $\mathrm{R}^{2}$ & .041 & .133 & .059 & .130 \\
\hline$\Delta \mathrm{R}^{2}$ & & .093 & -.07 & .08 \\
\hline F-value & $1.900 \dagger$ & $3.80^{* * *}$ & $2.14 *$ & $3.18^{* *}$ \\
\hline
\end{tabular}

$\dagger p<.10 ; * p<.05 ; * * p<.01$

innovative, and forward-looking opportunity-seeking and exploitation behavior, initiate a search process for new resources. EO positively influences new ventures' resource acquisition, extending expectations set in recent studies that EO can enable new ventures to collect and assemble resources from various sources (Jiang et al., 2018). However, we also theorize when and why this relationship is context sensitive, and in RBV terms, we show how the new venture must bear strategic orientations legitimate to resource holders given environmental boundary conditions. Our empirical results

Table 11 Endogeneity test: entrepreneurial experience instrumental variable test under low dynamic environment

\begin{tabular}{llll}
\hline Explaining variables & \multicolumn{2}{l}{ Explained variable:resource acquisition } \\
\cline { 2 - 4 } Controls & Yes & Yes & Yes \\
\hline EO & $.631^{*}$ & & \\
OO & & .900 & .187 \\
EO * OO & & .007 & .004 \\
Partial R & .000 & .943 & .576 \\
Partial R $2: \mathrm{F}$ & .014 & $.343 \dagger$ & $.296 \dagger$ \\
Hausman test & $.545^{*}$ & .000 & -.003 \\
Adj- R & -.007 & 147 & 147 \\
Observations & 147 & & \\
\hline
\end{tabular}

$\dagger p<.10 ; * p<.05 ; * * p<.01$ 
Table 12 Endogeneity test: heckman second-stage test under low dynamic environment

\begin{tabular}{llll}
\hline Explaining variables & \multicolumn{2}{l}{ Explained variable:resource acquisition } \\
\hline Firm age & -.179 & -.024 & -.048 \\
Firm size & 3.419 & $.255 \dagger$ & .306 \\
IT service & .000 & .053 & -.327 \\
Retailing & .000 & -.306 & -1.171 \\
Manufacturing & .000 & .150 & -.226 \\
General service & .000 & .338 & -.085 \\
Inverse Mills Ratio & -14.614 & 1.993 & -3.724 \\
EO & & $.620^{* * *}$ & -.292 \\
EO $*$ OO & & & .071 \\
Wald chi2 & .02 & $21.69 * *$ & 4.14 \\
Prob $>$ chi2 & .989 & .003 & .902 \\
\hline
\end{tabular}

$\dagger p<.10 ; * p<.05 ; * * p<.01$

validate this aspect of our theoretical model but with some caveats as to exactly how, when, and why EO can promote resource acquisition. We now discuss explanations for and implications from our findings before we set out how these contribute to theory, advance our knowledge of new ventures' successful resource acquisition, and strengthen the predictive accuracy surrounding EO and its systems of effects.

While previous studies frequently imply a positive relationship between EO and resource acquisition, oftentimes while attempting to map the causal mechanisms of its relationship with firm performance, this is rarely theoretically reasoned or empirically tested and ignores whether contextual factors influence any such relationship. We provide a theoretical framework and evidence to show this relationship is context specific among Chinese new ventures. EO will initiate behaviors to acquire resources concerned with its behaviors (risk-taking, innovativeness, proactiveness). These resources may have little use to those firms with an opportunistic orientation (OO), whose emphasis on imitation and narrow opportunistic exploitation of existing technology, would, on the surface, appear to render EO-related resources of relatively little use. We introduced $\mathrm{OO}$ as the moderating variable and examined its influence on the

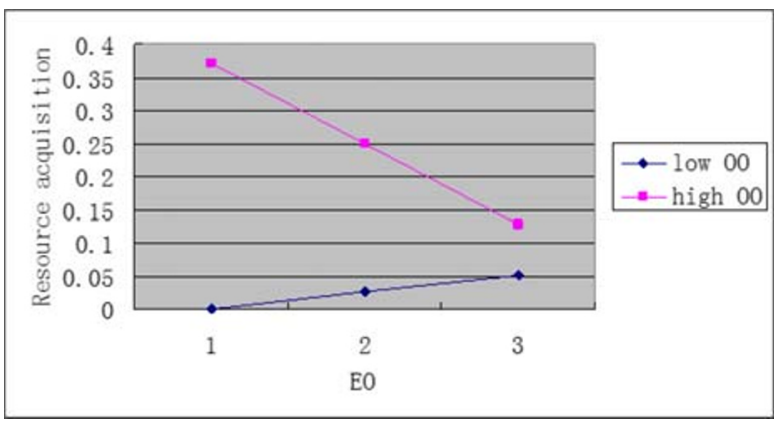

Fig. 2 Moderating effect of $\mathrm{OO}$ on the relationship between EO and resource acquisition under low dynamic environment 
relationship between $\mathrm{EO}$ and resource acquisition. $\mathrm{OO}$ is an important contextual variable that reflects specific elements of the Chinese context and business climate. This addition extends the nomological network of EO and one that helps us better understand its boundary conditions.

These relationships are subject to the dynamism characterizing the external environment of the new venture. We show that China cannot be considered in its entirety as bearing a highly dynamic environment only. There is variation among Chinese new ventures in the actual and perceived level of environmental dynamism they encounter, and that variation alters the effects we describe above. For example, we predicted that when moving from a high dynamic environment to a low dynamic environment, the effect of $\mathrm{OO}$ on the relationship between $\mathrm{EO}$ and new venture resource acquisition would change from complementary to substitutive. Our results show that OO has a negative moderating effect on the relationship between EO and resource acquisition under low dynamic environment. In this situation, utilizing both orientations to a high degree prevents resource holders from envisioning a clear strategic pathway to growth. The new venture loses legitimacy in the eyes of resource holders therefore, and resources are withheld. The two orientations, despite having positive individual effects on resources acquisition, become substitutive and deleterious when used in combination when environments are weakly dynamic. The results enrich previous studies by providing evidence of the contextual factors, both "OO" as an internal factor and "environmental dynamism" as an external factor, that determine under what conditions EO may facilitate resource acquisition. In low dynamic environments, This helps us understand the internal influencing mechanism between EO and resource acquisition under the complex Chinese context and provides fresh insight into the 'organizing mechanism' component of the RBV.

Unexpectedly, our empirical results do not support a complementary effect between $\mathrm{EO}$ and $\mathrm{OO}$ on new venture resource acquisition under a high dynamic environment. One possible reason is that OO plays a less important role under a highly dynamic environment than first anticipated, being neither complementary nor substitutive to EO. It was expected that the resource consumption intensity of EO and the high risk of failure and uncertainty surrounding very novel products, technologies and services would require a complementary $\mathrm{OO}$ to give resource holders the requisite confidence to unlock resources. But, theoretically, a high dynamic environment should also place a premium on innovation to distinguish the firm from its competitors and our findings extend this logic by showing the primacy of EO and a lack of complementarity from OO. Forward-looking innovation is also necessary as part of the currency for legitimacy with resource holders in highly dynamic environments. This explains the diminished effect of OO. For example, considering the mean and standard deviation of $\mathrm{OO}$ in Table 13; the mean of OO is lower than EO under high environmental dynamism. Another explanation is that under a high dynamic environment, acquiring new resources is difficult for new ventures because competition and rates of change in markets and technology are high. OO places emphasis on capitalizing first and foremost on existing resources orchestrated into market solutions that are imitative or closely additive to what exists already. The dynamic environment favors more entrepreneurial solutions to contest against emerging new opportunities such that imitative solutions become outdated or unsustainable. Extending RBV logic then, new ventures with a high EO above all are the best organizing mechanism to create wealth in such 
Table 13 Descriptive statistics under high dynamic environment

\begin{tabular}{lllllc}
\hline & Number & Minimum & Maximum & Mean & Std. Deviation \\
\hline EO & 111 & 2.000 & 7.000 & 5.179 & .9291 \\
OO & 107 & 1.670 & 7.000 & 5.111 & 1.009 \\
Innovation & 114 & 1.000 & 7.000 & 5.409 & 1.224 \\
Risk-taking & 113 & 1.000 & 7.000 & 4.891 & 1.275 \\
Proactiveness & 112 & 1.330 & 7.000 & 5.131 & 1.178 \\
Valid N (listwise) & 104 & & & & \\
\hline
\end{tabular}

conditions. A high EO overrides any contribution from $\mathrm{OO}$ in this situation, muting any effect it may have not he relationship between EO and new ventures' success at resource acquisition.

\section{Contributions}

First, in examining the relationship between EO and resource acquisition we reveal how EO plays its role in new ventures. Our research builds the connection between EO and the resource-based view (RBV), calls for which have long stood in the literature because of its potential to enrich entrepreneurial theory (Jiang et al., 2018; Wiklund \& Shepherd, 2003). Extending the RBV, we overcome deficits in existing theory that do not explain the mechanisms by which EO may help or hinder new venture resource acquisition (e.g., Huang, Wang, Tseng, \& Wang, 2010; Jiang et al., 2018). We theorized and evidenced that EO is beneficial for resource acquisition in part because it triggers a search process for new resource providers, can shape new internal resources to form, and persuade others to invest resources in the venture. This evidence implies that EO contains a legitimization feature because of its positive relationship with resource acquisition in our study. Specifically, innovativeness needs new ventures to explore unique resources to introduce new products and services and undermine their competitors (Huang et al., 2010); risk-taking fosters new ventures to seek new resources (Hughes \& Morgan, 2007); and proactiveness reflects new ventures with a tendency to maintain first-mover advantage in the short term and expect the future direction of market environment in the long term (Hughes \& Morgan, 2007). This result answers the question of how EO plays its role in new ventures and contributes to theory insight on a vital first step before which EO may improve new ventures' performance. In summary, we provide a theoretical logic that sees EO as a resource-intensive orientation that initiates a search process to acquire resources to both refuel the new venture and to enable its entrepreneurially-oriented endeavors to come to life.

Second, we reveal that the success of EO in enabling resource acquisition by new ventures will depend on contextual factors. We enrich the study of EO and the RBV by integrating $\mathrm{OO}$, a second strategic orientation prevalent in the Chinese context for entrepreneurship. Covin and Wales (2019) argued that EO can be disruptive and unproductive in ways that suggest a second complementary orientation that promotes stability and focus is necessary to optimize its contribution. We conceptualize OO (Anokhin et al., 2010, 2011) as one orientation. Our research builds the connection 
between EO and the RBV, calls for which have long stood in the literature because of its potential to enrich entrepreneurial theory (Jiang et al., 2018; Wiklund \& Shepherd, 2003). OO is salient for new ventures because it transforms classic notions of arbitrage into a strategic posture particularly reflective of the Chinese context. For example, during a transitional economy period, market demand is frequently uncertain and difficult to predict; information cannot transfer from one actor to another smoothly, which makes the pricing mechanism ineffective and temporary. Many entrepreneurs then create ventures by making use of information asymmetry-an opportunistic endeavor enabling the venture to buy inputs at a low price and sell outputs at a high price. Because institutions are unstable (Cui et al., 2018), widespread opportunistic behaviors occurs, becoming a modus operandi for many new ventures. Yet, new technologies and technology updates and upgrades are frequent in China. These conditions attract competition, and some entrepreneurs imitate to reduce their innovation costs (Anokhin \& Wincent, 2014). On the culture side, most Chinese people are also risk averse and prefer stability (Ma et al., 2015), which is why many entrepreneurs imitate an not innovate. In revealing the importance of $\mathrm{OO}$ as a moderator of the relationship between EO and resource acquisition, we advance knowledge of a new internal organizational contingency acting on the contributions of EO to new venture resource acquisition. Our theoretical treatise and framework can explain differences in how EO may, on occasions, be productive and unproductive in resource acquisition terms.

Third, although scholars have recognized the importance of context to the study of EO and further unravelling its nomological network, scholars continue to call for actual work (Fayaz \& Shah, 2017) that goes beyond the study of typical institutions seen among analyses of entrepreneurship in China (Bruton, Zahra, \& Cai, 2018). Even where existing studies claim to treat the Chinese context, these studies often do so as background only (Jia et al., 2012; Zheng \& Zhao, 2017), and treat context as kittle more than control variables (Zahra et al., 2014; Yiu et al., 2018). Our study contributes to closing this research gap around the context sensitivity of EO. We show that the moderating effect of $\mathrm{OO}$ on the relationship between $\mathrm{EO}$ and resource acquisition changes between a high dynamic environment and a low dynamic environment. Configurational studies of EO have sought to answer the question why scholars have observed different results in the contribution of EO to outcomes important for new ventures (Hughes et al., 2007; Kearney, Soleimanof, \& Wales, 2018). We provide new insight into when and why EO is especially beneficial for new ventures or when its effects may be lost, locating the matter to the degree of environmental dynamism. Under a low dynamic environment, EO and OO are substitutive as an attempt to use $\mathrm{OO}$ at the same time as EO to increasingly high levels harms the contribution EO can make to new venture resource acquisition. When environmental dynamism is high, the effect disappears, being neither deleterious nor beneficial, and either orientation supports resource acquisition. These findings identify new contingencies to improve our predictive accuracy about EO and its system of effects.

\section{Managerial implications}

EO relies on the timely provision of resources to bear any effect on business activity let alone its performance frontier. In turn, studies report the importance of replenishing 
resources (Hughes et al., 2015). But we find that context changes the conditions for EO to enable resource acquisition. When new ventures operate with EO, they establish a powerful basis on which to attract, acquire and generate resources. EO consumes many resources to enact entrepreneurial activities commensurate with its behaviors and this activates a search process in which EO itself legitimizes the firm to gain actual access and acquire those resources subsequently. But its effects are context sensitive. New ventures simultaneously exhibiting EO and $\mathrm{OO}$ should carefully prioritize which orientation to emphasize when seeking to acquire resources. In a highly dynamic environment, either is powerful and OO has no bearing on the contribution of EO to accessing and acquiring resources from resource holders. But in a weakly dynamic environment, $\mathrm{OO}$ is deleterious to EO initiatives such that managers should prioritize and use one or the other but not both.

\section{Limitation and future directions}

Despite the promise of our insights, our findings are subject to limitations. First, our sample is relatively small. Future research should extend our sample scale and include more geographic areas of China, such as southwestern areas and northwestern areas to capture a greater spread of environmental dynamism. An extension of our sample to a larger population and number of locations would enhance the generalizability of our promising results.

Second, this research is based on a cross-sectional design; however, establishing causality requires longitudinal data. In future, it is beneficial for scholars to study how EO plays its role longitudinally and seek historical data where possible to examine our model. We forewarn scholars, however, that reliable objective data, especially of a longitudinal nature, is challenging to obtain in China and unavailable in many instances. Creativity in data and measurement will be needed, or alternative research designs.

Third, our study treated EO as a unidimensional variable. How the different dimensions of EO might influence resource acquisition may require study. For example, is innovativeness helpful for new ventures to acquire talented human resources capable of further innovative actions? Does risk-taking lead new ventures to build more relationships with other market players and acquire more information important to acquiring new resources? Does proactiveness require new ventures to acquire more financial resources? In future, these questions should be examined in different environmental conditions to rigorously address the uniqueness of the Asian context.

Fourth, beyond the moderating effect of $\mathrm{OO}$ on the relationship between EO and resource acquisition, an inquiry into the relationship between $\mathrm{OO}$ and $\mathrm{EO}$ requires further investigation. $\mathrm{EO}$ and $\mathrm{OO}$ appear to create a tension when environmental dynamism is low, becoming substitutive rather than complementary, because of the deleterious moderating effect $\mathrm{OO}$ had on the relationship between EO and new venture acquisition. In a high dynamic environment, this tension either disappears or bears no influence. Discovering why this is so has the potential to yield new insights into an apparent tensions and paradox emerging from our findings.

Finally, our results are generated from new ventures in the Chinese emerging economy. We encourage future studies not to limit tests of these relationships to China alone but expand into other Asian counties and make comparisons with other emerging 
economies and with developed economies. For example, in distinguishing between different types of emerging economies, future research can extend the usefulness of our findings for the form and effect of EO and $\mathrm{OO}$ in specific types of emerging economies.

\section{Conclusion}

Little is known about the manner in which EO influences new venture outcomes and little has been done to examine the moderating effect of contextual variables. Yet, context is the soul of Asian management research (Yiu et al., 2018). Our study advances knowledge by theorizing and evidencing how, why, and when EO influences resource acquisition to improve new venture resource acquisition, incorporating contextual variables seldom in receipt of sufficient scholarly attention. We introduce OO as a moderator to reflect opportunistic behavior prevalent, but not unique to, the Chinese context and evidence how OO moderates the relationship between EO and resource acquisition under high and low environmental dynamism as additional contextual features. In a low dynamic environment, OO negatively moderates the relationship between EO and resource acquisition. But under high dynamic environment, the moderating effect is not significant. Our research responds to calls by researchers and managers for the key processes and contextual boundary conditions explaining how EO play its role in new ventures in emerging economies (Hughes et al., 2018b; Zahra et al., 2014).

Acknowledgements We appreciate insightful comments and helpful guidance from two anonymous reviewers in the review process. The study is supported by the Nation Natural Science Foundation of China (Grant no. 71972085).

Open Access This article is licensed under a Creative Commons Attribution 4.0 International License, which permits use, sharing, adaptation, distribution and reproduction in any medium or format, as long as you give appropriate credit to the original author(s) and the source, provide a link to the Creative Commons licence, and indicate if changes were made. The images or other third party material in this article are included in the article's Creative Commons licence, unless indicated otherwise in a credit line to the material. If material is not included in the article's Creative Commons licence and your intended use is not permitted by statutory regulation or exceeds the permitted use, you will need to obtain permission directly from the copyright holder. To view a copy of this licence, visit http://creativecommons.org/licenses/by/4.0/.

\section{References}

Ahlstrom, D., \& Bruton, G. D. 2006. Venture capital in emerging economies: Networks and institutional change. Entrepreneurship Theory and Practice, 30(2): 299-320.

Anderson, J. C., \& Gerbing, D. W. 1988. Structural equation modeling in practice: A review and recommended two-step approach. Psychological Bulletin, 103(3): 411-423.

Anokhin, S., \& Wincent, J. 2014. Technological arbitrage opportunities and interindustry differences in entry rates. Journal of Business Venturing, 29(3): 437-452.

Anokhin, S., Troutt, M. D., Wincent, J., \& Brandyberry, A. A. 2010. Measuring arbitrage opportunities: A minimum performance inefficiency estimation technique. Organizational Research Methods, 13(1): 5566.

Anokhin, S., Wincent, J., \& Autio, E. 2011. Operationalizing opportunities in entrepreneurship research: Use of data envelopment analysis. Small Business Economics, 37(1): 39-57. 
Armstrong, J. S., \& Overton, T. S. 1977. Estimating nonresponse bias in mail surveys. Journal of Marketing Research, 14(3): 396-402.

Bamford, C. E., Dean, T. J., \& Douglas, T. J. 2004. The temporal nature of growth determinants in new bank foundings: Implications for new venture research design. Journal of Business Venturing, 19(6): 899-919.

Barney, J. 1991. Firm resources and sustained competitive advantage. Journal of Management, 17(1): 99-120.

Barney, J., Wright, M., \& Ketchen Jr, D. J. 2001. The resource-based view of the firm: Ten years after 1991. Journal of Management, 27: 625-641.

Batjargal, B. 2007. Internet entrepreneurship: Social capital, human capital, and performance of internet ventures in China. Research Policy, 36(5): 605-618.

Berger, R., Herstein, R., Silbiger, A., \& Barnes, B. R. 2018. Is guanxi universal in China? Some evidence of a paradoxical shift. Journal of Business Research, 86: 344-355.

Brush, C. G., Greene, P. G., \& Hart, M. M. 2001a. From initial idea to unique advantage: The entrepreneurial challenge of constructing a resource base. Academy of Management Perspectives, 15:64-78.

Brush, C. G., Greene, P. G., Hart, M. M., \& Haller, H. S. 2001b. From initial idea to unique advantage: The entrepreneurial challenge of constructing a resource base. Academy of Management Executive, 15: 64-80.

Bruton, G. D., Zahra, S. A., \& Cai, L. 2018. Examining entrepreneurship through indigenous lenses. Entrepreneurship Theory and Practice, 42(3): 351-361.

Cai, L., Hughes, M., \& Yin, M. 2014. The relationship between resource acquisition methods and firm performance in Chinese new ventures: The intermediate effect of learning capability. Journal of Small Business Management, 52(3): 365-389.

Cai, L., Anokhin, S., Yin, M., \& Hatfield, D. E. 2016. Environment, resource integration, and new ventures' competitive advantage in China. Management and Organization Review, 12(2): 333-356.

Chan, H. K., Yee, R. W. Y., Dai, J., \& Ming, K. L. 2016. The moderating effect of environmental dynamism on green product innovation and performance. International Journal of Production Economics, 181: 384391.

Chiu, C. K., Chien, C. S., Lin, C. P., \& Hsiao, C. Y. 2005. Understanding hospital employee job stress and turnover intentions in a practical setting: The moderating role of locus of control. Journal of Management Development, 24(10): 837-855.

Covin, J. G., \& Miller, D. 2014. International entrepreneurial orientation: Conceptual considerations, research themes, measurement issues, and future research directions. Entrepreneurship Theory and Practice, 38(1): 11-44.

Covin, J. G., \& Slevin, D. P. 1989. Strategic management of small firms in hostile and benign environments. Strategic Management Journal, 10(1): 75-87.

Covin, J. G., \& Slevin, D. P. 1991. A conceptual model of entrepreneurship as firm behavior. Entrepreneurship Theory and Practice, 16(1): 7-25.

Covin, J. G., \& Wales, W. 2019. Crafting high-impact entrepreneurial orientation research: Some suggested guidelines. Entrepreneurship Theory and Practice, 43(1): 3-18.

Cui, L., Fan, D., Guo, F., \& Fan, Y. 2018. Explicating the relationship of entrepreneurial orientation and firm performance: Underlying mechanisms in the context of an emerging market. Industrial Marketing Management, 71: 27-40.

Dong, W., Ma, Z., \& Zhou, X. 2017. Relational governance in supplier-buyer relationships: The mediating effects of boundary spanners' interpersonal guanxi in China's B2B market. Journal of Business Research, 78: $332-340$.

Doorn, S. V., Heyden, M. L. M., \& Volberda, H. W. 2017. Enhancing entrepreneurial orientation in dynamic environments: The interplay between top management team advice-seeking and absorptive capacity. Long Range Planning, 50(2): 134-144.

Fayaz, M., \& Shah, S. A. 2017. Relationship between entrepreneurial orientation and firm performance: Mediation of transformational leadership in the context of Pakistani SMEs. Journal of Managerial Sciences, 11:469-484.

Fornell, C., \& Larcker, D. F. 1981. Evaluating structural equation models with unobservable variables and measurement error. Journal of Marketing Research, 18(1): 39-50.

Gao, J. 2006. Global entrepreneurship monitor China report. Beijing: Tsinghua University Press.

Goll, I., \& Rasheed, A. A. 2004. The moderating effect of environmental munificence and dynamism on the relationship between discretionary social responsibility and firm performance. Journal of Business Ethics, 49(1): 41-54.

Green, K. M., Covin, J. G., \& Slevin, D. P. 2008. Exploring the relationship between strategic reactiveness and entrepreneurial orientation: The role of structure-style fit. Journal of Business Venturing, 23(3): 356-383.

Gupta, R. 2019. Entrepreneurship orientation, resources, and small firm growth: Evidence from India. International Journal of Business and Economics, 18(1): 41-58. 
Huang, K. P., \& Wang, K. Y. 2013. The moderating effect of social capital and environmental dynamism on the link between entrepreneurial orientation and resource acquisition. Quality \& Quantity, 47(3): 16171628.

Huang, K. P., Wang, C. H., Tseng, M. C., \& Wang, K. Y. 2010. A study on entrepreneurial orientation and resource acquisition: The effects of social capital. African Journal of Business Management, 4(15): 32263231.

Hughes, M., \& Morgan, R. E. 2007. Deconstructing the relationship between entrepreneurial orientation and business performance at the embryonic stage of firm growth. Industrial Marketing Management, 36(5): 651-661.

Hughes, P., \& Morgan, R. E. 2008. Fitting strategic resources with product-market strategy: Performance implications. Journal of Business Research, 61(4): 323-331.

Hughes, M., Hughes, P., \& Morgan, R. E. 2007. Exploitative learning and entrepreneurial orientation alignment in emerging young firms: Implications for market and response performance. British Journal of Management, 18(4): 359-375.

Hughes, M., Morgan, R. E., Ireland, R. D., \& Hughes, P. 2014. Social capital and learning advantages: A problem of absorptive capacity. Strategic Entrepreneurship Journal, 8(3): 214-233.

Hughes, M., Eggers, F., Kraus, S., \& Hughes, P. 2015. The relevance of slack resource availability and networking effectiveness for entrepreneurial orientation. International Journal of Entrepreneurship \& Small Business, 16(1): 116-138.

Hughes, P., Hodgkinson, I. R., Arshad, D., Hughes, M., \& Leone, V. 2018a. Planning to improvise? The role of reasoning in the strategy process: Evidence from Malaysia. Asia Pacific Journal of Management, 35(2): 449-470.

Hughes, P., Hodgkinson, I.R., Hughes, M., \& Arshad, D. 2018b. Explaining the entrepreneurial orientationperformance relationship: The intermediate roles of absorptive capacity and improvisation. Asia Pacific Journal of Management, 35: 1025-1053.

Jia, L., You, S., \& Du, Y. 2012. Chinese context and theoretical contributions to management and organization research: A three-decade review. Management and Organization Review, 8(1): 173-209.

Jiang, X., Liu, H., Fey, C., \& Jiang, F. 2018. Entrepreneurial orientation, network resource acquisition, and firm performance: A network approach. Journal of Business Research, 87: 46-57.

Jiang F., Wang G., \& Jiang X. 2019. Entrepreneurial orientation and organizational knowledge creation: A configurational approach. Asia Pacific Journal of Management, 36: 1193-1219.

Kearney, C., Soleimanof, S., \& Wales, W. J. 2018. Examining facilitative configurations of entrepreneurially oriented growth: An information processing perspective. British Journal of Management, 29(3): 514-533.

Keh, H. T., Nguyen, T. T. M., \& Ng, H. P. 2007. The effects of entrepreneurial orientation and marketing information on the performance of SMEs. Journal of Business Venturing, 22(4): 592-611.

Khan, A.M., \& Manopichetwattana, V. (1989). Innovative and noninnovative small firms: types and characteristics. Management Science, 35: 597-606.

Koberg, C. S., Detienne, D. R., \& Heppard, K. A. 2003. An empirical test of environmental, organizational, and process factors affecting incremental and radical innovation. Journal of High Technology Management Research, 14:21-45.

Kor, Y. Y., \& Mahoney, J. T. 2004. Edith Penrose's (1959) contributions to the resource-based view of strategic management. Journal of Management Studies, 41(1): 183-191.

Kraus, S., Rigtering, C., Hughes, M., \& Hosman, V. 2012. Entrepreneurial orientation and the business performance of SMEs: A quantitative study from the Netherlands. Review of Managerial Science, 6(2): 161-182.

Le Mens, G., Hannan, M., \& Polos, L. 2015. Age-related structural inertia: A distance-based approach. Organization Science, 26(3), 756-773.

Lee, T. \& Chu, W. 2013. How entrepreneurial orientation, environmental dynamism, and resource rareness influence firm performance. Journal of Management \& Organization, 19(2): 167-187.

Levinthal, D. A., \& March, J. G. 1993. The myopia of learning. Strategic Management Journal, 14: 95-112.

Li, D. Y., \& Liu, J. 2014. Dynamic capabilities, environmental dynamism, and competitive advantage: Evidence from China. Journal of Business Research, 67(1): 2793-2799.

Li, H., \& Zhang, Y. 2007. The role of managers' political networking and functional experience in new venture performance: Evidence from China's transition economy. Strategic Management Journal, 28(8): 791-804.

Lin, Z., Yang, H., \& Arya, B. 2009. Alliance partners and firm performance: Resource complementarity and status association. Strategic Management Journal, 30(9): 921-940.

Lumpkin, G. T., \& Dess, G. G. 1996. Clarifying the entrepreneurial orientation construct and linking it to performance. Academy of Management Review, 21(1): 135-172. 
Luo, Y., Sun, J. Y., \& Wang, S. L. 2011. Emerging economy copycats: Capability, environment, and strategy. Academy of Management Perspectives, 25(2): 37-56.

Ma, Z., Yu, M., Gao, C., Zhou, J., \& Yang, Z. 2015. Institutional constraints of product innovation in China: Evidence from international joint ventures. Journal of Business Research, 68(5): 949-956.

Martens, M. L., Jennings, J. E., \& Jennings, P. D. 2007. Do the stories they tell get them the money they need? The role of entrepreneurial narratives in resource acquisition. Academy of Management Journal, 50(5): 1107-1132.

Miller, D. 1983. The correlates of entrepreneurship in three types of firms. Management Science, 29(7): 770791.

Miller, D. 1987. The structural and environmental correlates of business strategy. Strategic Management Journal, 8(1): 55-76.

Miller, D. 2011. Miller (1983) revisited: A reflection on EO research and some suggestions for the future. Entrepreneurship Theory and Practice, 35(5): 873-894.

Min, H., Park, J., \& Kim, H. J. 2016. Common method bias in hospitality research: A critical review of literature and an empirical study. International Journal of Hospitality Management, 56: 126-135.

Spector, P. E. (2016) Method variance in organizational research. Organizational Research Methods, 9(2): 221-232.

Patel, P. C., Kohtamäki, M., Parida, V., \& Wincent, J. 2015. Entrepreneurial orientation-as-experimentation and firm performance: The enabling role of absorptive capacity. Strategic Management Journal, 36: 1739-1749.

Penrose, E. T. 1959. The theory of the growth of the firm. New York: John Wiley.

Peterson, R. A. 2000. Constructing effective questionnaires. Thousand Oaks: Sage.

Podsakoff, P. M., MacKenzie, S. B., Lee J.Y., \& Podsakoff, N. P. 2003. Common method biases in behavioral research: A critical review of the literature and recommended remedies. Journal of Applied Psychology, 88(5): 879-903.

Podsakoff, P. M., MacKenzie, S. B., \& Podsakoff, N. P. 2012. Sources of method bias in social science research and recommendations on how to control it. Annual Review of Psychology, 63: 539-569.

Rogelberg, S. G., \& Stanton, J. M. 2007. Introduction: Understanding and dealing with organizational survey nonresponse. Organizational Research Methods, 10(2): 195-209.

Saeed, S., Yousafzai, S. Y., \& Engelen, A. 2014. On cultural and macroeconomic contingencies of the entrepreneurial orientation-performance relationship. Entrepreneurship Theory and Practice, 38(2): 255-290.

Semrau, T., Ambos, T., \& Kraus, S. 2016. Entrepreneurial orientation and SME performance across societal cultures: An international study. Journal of Business Research, 69: 1928-1932.

Shou, Z., Chen, J., Zhu, W., \& Yang, L. 2014. Firm capability and performance in China: The moderating role of guanxi, and institutional forces in domestic and foreign contexts. Journal of Business Research, 67(2): 77-82.

Sine, W. D., Mitsuhashi, H., \& Kirsch, D. A. 2006. Revisiting Burns and Stalker: Formal structure and new venture performance in emerging economic sectors. Academy of Management Journal, 49(1): 121-132.

Sirmon, D. G., Hitt, M. A., Ireland, R. D., \& Gilbert, B. A. 2011. Resource orchestration to create competitive advantage: Breadth, depth, and life cycle effects. Journal of Management, 37(5): 1390-1412.

Spector, P. E. (2006). Method variance in organizational research: Truth or urban legend? Organizational Research Methods, 9(2): 221-232. 1 I attempted to insert this into the references list. It currently sits at the very bottom of the list and will need editing.

Venkatraman, N., \& Camillus, J. 1984. Exploring the concept of 'fit' in strategic management. Academy of Management Review, 9(3): 513-525.

Wales, W. J., Patel, P. C., Parida, V., \& Kreiser, P. M. 2013. Nonlinear effects of entrepreneurial orientation on small firm performance: The moderating role of resource orchestration capabilities. Strategic Entrepreneurship Journal, 7(2): 93-121.

Wernerfelt, B. 1984. A resource-based view of the firm. Strategic Management Journal, 5: 171-180. 
Wiklund, J., \& Shepherd, D. 2003. Knowledge-based resources, entrepreneurial orientation, and the performance of small and medium-sized businesses. Strategic Management Journal, 24(13): 1307-1314.

Wiklund, J., \& Shepherd, D. 2005. Entrepreneurial orientation and small business performance: A configurational approach. Journal of Business Venturing, 20(1): 71-91.

Yiu, D. W., Lam, L. W., Gaur, A., Lee, S.-H., \& Wong, C.-S. 2018. Asian relevance, global impact: Asian management research entering a new era. Asia Pacific Journal of Management, 35: 565-571.

Zahra, S. A., Wright, M., \& Abdelgawad, S. G. 2014. Contextualization and the advancement of entrepreneurship research. International Small Business Journal, 32(5): 479-500.

Zhang, J., Soh, P. H., \& Wong, P. 2010. Entrepreneurial resource acquisition through indirect ties: Compensatory effects of prior knowledge. Journal of Management, 36(2): 511-536.

Zheng, L., \& Zhao, Z. 2017. What drives spatial clusters of entrepreneurship in China? Evidence from economic census data. China Economic Review, 46: 229-248.

Zhou, K. Z., \& Li, C. B. 2010. How strategic orientations influence the building of dynamic capability in emerging economies. Journal of Business Research, 63(3): 224-231.

Zhou, K. Z., \& Poppo, L. 2010. Exchange hazards, relational reliability, and contracts in China: The contingent role of legal enforceability. Journal of International Business Studies, 41(5): 861-881.

Publisher's note Springer Nature remains neutral with regard to jurisdictional claims in published maps and institutional affiliations.

Yin Miaomiao is Professor of Entrepreneurship at Jilin University, Changchun, China. Her research interests include entrepreneurial orientation and new ventures. She has published in such journals as Journal of Small Business Management and Management and Organization Review.

Mathew Hughes is Professor of Entrepreneurship and Innovation at the School of Business and Economics at Loughborough University, UK, having previously served at Durham University and University of Nottingham. Mat has published widely on matters of entrepreneurial orientation and innovation in such journals as Asia Pacific Journal of Management, Strategic Entrepreneurship Journal, Journal of Product Innovation Management and British Journal of Management. He sits on several editorial review boards including Journal of Management Studies, Journal of Business Venturing, British Journal of Management and the Journal of Family Business Strategy. Mat is also a Co-Editor of the Entrepreneurship Research Journal.

Qilin Hu is Lecturer in Business and Management at Leicester Castle Business School at De Montfort University, UK. His research interests focus on innovation and the family business.

\section{Affiliations}

\section{Miaomiao Yin ${ }^{1} \cdot$ Mathew Hughes ${ }^{2} \cdot{\text { Qilin } \mathrm{Hu}^{3}}^{3}$}

1 Jilin University, School of Management, Changchun, Jilin, China

2 Loughborough University, School of Business and Economics, Loughborough, Leicestershire LE11 $3 \mathrm{TU}, \mathrm{UK}$

3 De Montfort University, Leicester Castle Business School, Leicester LE1 9BH, UK 